\title{
The Edwards Aquifer: Earth's Most Diverse Groundwater Ecosystem?
}

\author{
Glenn Longley*
}

\author{
SUMMARY
}

Recent studies on the Edwards Aquifer, a karstic formed cavernous system in Texas, indicate an extremely diverse community of aquatic troglobites. Sampling of wells and springs is providing new insight into the dynamics of this fascinating system, which is possibly the most diverse subterranean aquatic ecosystem known in the world today.

The Edwards Aquifer is found in association with the Balcones Escarpment in central Texas. The Balcones Escarpment and Fault Zone is the dominant structural feature in the area, and the major faults occur as a series of closely spaced step faults that trend eastward in Kinney County to Bexar County area then northeastward from Bexar County to Hays County. The Edwards Aquifer is a porous, honeycombed, cavernous limestone that consists of fine grained carbonate rocks between the base of the Del Rio Clay and the top of the Glen Rose Formation. The thickness of the porous beds of Edwards limestone varies between 122 and $152 \mathrm{~m}$ (Puente, 1976). The aquifer is about 282 $\mathrm{km}$ long, from 8 to $64 \mathrm{~km}$ wide, and has two major features: the recharge area and the artesian area (Fig. 1). The water entering the aquifer moves first southward from the Edwards Plateau then eastward and northeastward toward large natural outlets at Comal Springs in New Braunfels and San Marcos Springs in San Marcos. Other discharges from the aquifer are Leona Springs in Uvalde, San Antonio and San Pedro Springs in San Antonio, and Hueco Springs north of New Braunfels. An illustration of the possible structure of the cavernous Edwards is given in Figure 2. This indicates the possible relationship between flow and the top of the piezometric surface (Arnow, 1959). Many wells have been drilled into the artesian part of the aquifer, and many of them in the San Antonio area flow at ground level. The fauna occurring in the aquifer, springs, and flowing artesian wells were sampled during the studies. In a few instances, pumped wells were sampled.

Recharge averages more than $616 \mathrm{hm}^{3}$ (cubic hectometers). The total amount of water stored in the aquifer is not known. During the period 1934

* Director, Edwards Aquifer Research / Data Center. Aquatic Station (Biology Department) Southwest Texas State University San Marcos, Texas 78666. 


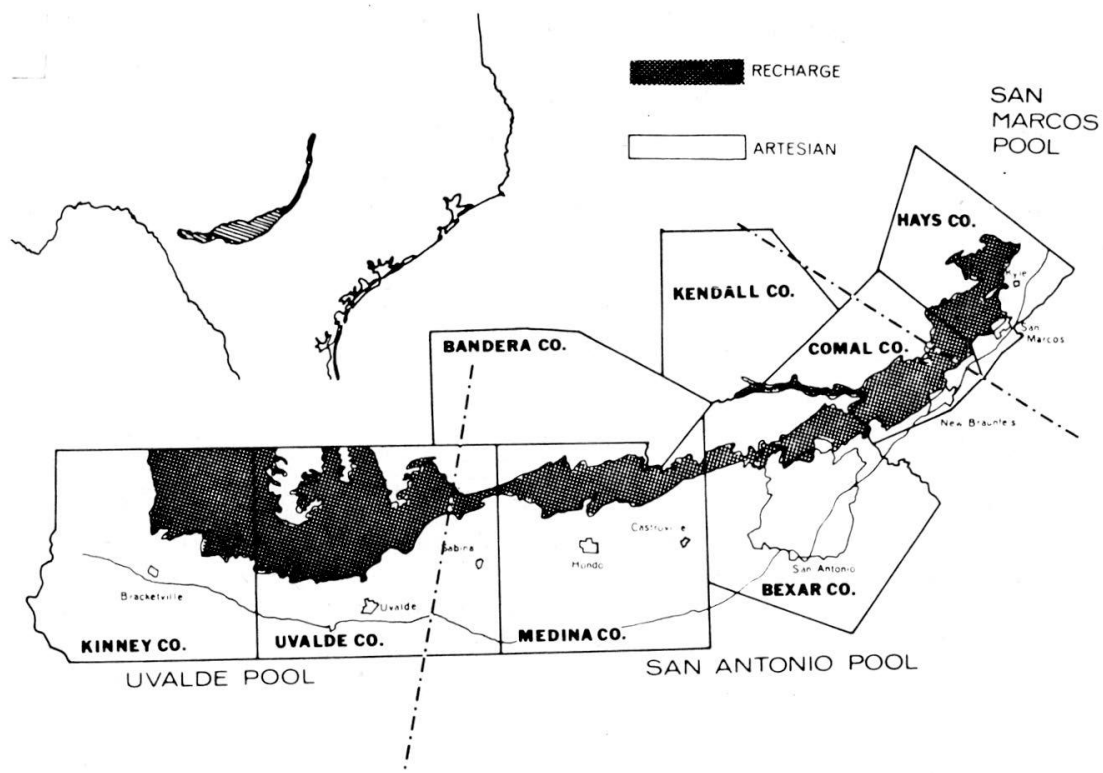

Fig. 1. Edwards Aquifer.

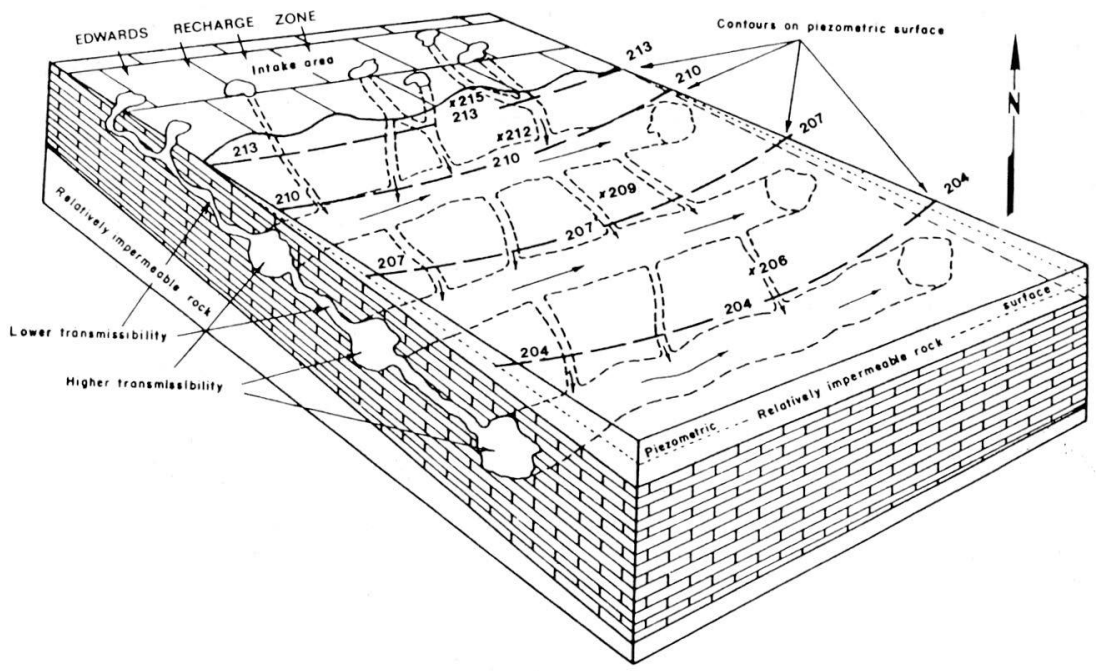

Fig. 2. Hypothetical diagram of flow in the Edward Aquifer. 
to 1975 , a minimum recharge of $54.25 \mathrm{hm}^{3}$ occurred in 1956 and a maximum recharge of $2,096 \mathrm{hm}^{3}$ occurred in 1958 . In $1971,501.58 \mathrm{hm}^{3}$ were pumped from the aquifer, the highest amount on record (Edwards Underground Water District, 1977). Estimates of water use in the future, due to increased population pressure, indicate that discharge by pumping will exceed recharge and all of the springs will eventually dry (U.S. Department of the Interior, 1973).

The aquifer is divided into three areas hydrologically: the Uvalde Pool, San Antonio (or Central) Pool, and San Marcos Pool. These areas are connected during times when the piezometric levels are high. During periods of severe drought, it can be expected that water in these areas will be separated by some distance. There is some biological evidence that these high points at the base of the aquifer may be factors limiting the distribution of organisms. An example may be the presence of two species of highly adapted cave salamanders Typhlomolge rathbuni and Typhlomolge robusta, in the San Marcos Pool, (Longley, 1978) and their absence in the San Antonio Pool. Two species of blind catfishes, Satan eurystomus (Longley and Karnei, 1978a) and Trogloglanis pattersoni (Longley and Karnei, 1978b), are the top of the food chain in the San Antonio pool. All four of these vertebrates occur in the artesian region of the aquifer.

Other aquatic vertebrates that occur in caves of the recharge zone of the aquifer are species of the salamander genus Eurycea. These include Eurycea tridentifera (Honey Creek Cave Salamander), Eurycea troglodytes (Valdina Farms Sinkhole Salamander) now thought to be a hybrid swarm between $E$. neotenes and E. tridentifera (Sweet, 1978), Eurycea latitans (Cascade Cavern Salamander), and Eurycea neotenes (an occasional inhabitant of caves from which springs flow.

The Edwards Aquifer has a wide variety of aquatic invertebrates. The troglobitic species are listed in Table 1 . In addition to those mentioned in Table 1 , there are several other species which are certainly troglophilic and may be considered troglobitic by some.

In the San Marcos area, the aquifer is very narrow and the recharge zone is near the entire artesian area. It is easy to visualize local recharge of organic matter as the primary source of energy into the subterranean aquatic system. Numerous caves occur in the recharge zone, near or in stream channels, and they probably account for large amounts of allochthonous debris. In the San Antonio area the aquifer is very wide, and some of the wells yielding aquatic troglobites in southern Bexar County are $32 \mathrm{~km}$ from the nearest known recharge area. These same wells are very near (often less than $1.5 \mathrm{~km}$ ) to the "bad water zone." The wells in the "bad water zone" have high total solids, sulfur compounds, high temperatures, and are also anaerobic. The Edwards formation dips downward to the south. Down dip from the deep wells in Bedar County oil occurs in the Edwards formation. The wells sampled in southern Bexar County were as much as $609 \mathrm{~m}$ deep. These same wells are known to produce small amounts of oil. The amount of oil produced seems to increase when the artesian pressure in the aquifer lowers. The blind catfish are found in these wells along with a varied invertebrate fauna. It is unlikely, 
Table 1. Troglobitic aquatic invertebrate fauna of the Edwards Aquifer.

\begin{tabular}{ll}
\hline \multicolumn{1}{c}{ TAXA } & \multicolumn{1}{c}{ LOCATION } \\
\hline $\begin{array}{l}\text { Phylum Platyhelminthes } \\
\text { Sphalloplana mohri }\end{array}$ & Hays Co., Medina Co. \\
Phylum Mollusca & \\
Horatia (Hauffenia) micra & Hays Co., Comal Co. \\
Species A (snail) & Hays Co. \\
Species B (snail) & Bexar Co. \\
Species C (snail) & Bexar Co. \\
Phylum Annelida & \\
Species A (Hirudinea) & Hays Co. \\
Phylum Arthropoda & \\
Candona sp. (ostracod) & Medina Co. \\
Species A (ostracod) & Hays Co. \\
Cyclops spp. (copepods) & Hays Co., Bexar Co., Uvalde Co. \\
Lirceolus smithii (isopod) & Hays Co., Uvalde Co. \\
Cirolanides texensis (isopod) & Hays Co., Bexar Co., \\
& Uvalde Co., Comal Co. \\
Cirolanidae (undescribed) (isopod) & Bexar Co., Uvalde Co. \\
Stenasellidae (undescribed) (isopod) & Bexar Co. \\
Monodella texana (Thermosbaenacea) & Hays Co., Bexar Co., Uvalde Co. \\
Stygobromus flagellatus (amphipod) & Hays Co., Bexar Co., Uvalde Co. \\
Stygobromus russelli (amphipod) & Hays Co., Comal Co. \\
Stygobromus pecki (amphipod) & Comal Co. \\
Seborgia sp. (amphipod) & Hays Co. \\
Plus 8 other amphipod species (I new & Hays Co., Bexar Co., \\
family, 4 new genera)* & Comal Co. \\
Palaemonetes antrorum (shrimp) & Hays Co., Bexar Co. \\
Palaemonetes holthuisi & Hays Co. \\
Haideoporus texanus (beetle) & Hays Co. \\
\hline & \\
\hline &
\end{tabular}

* See Holsinger and Longley 1980.

due to distance and hydrology, that organic matter washed into the aquifer in the recharge zone is reaching these deep wells. It should be noted that in the strata above the aquifer in this area there are deposits of oil and peat. Oil is being pumped in this area.

I propose a hypothesis regarding the energy input into the aquatic ecosystem in this part of the aquifer. I contend that the organic matter down dip in the Edwards is continuously migrating up the strata until it contacts the "good Edwards" water. The samples from wells contain large amounts of material that mycologists have described as mycelia from fungi. My concept of the food chain in this system is that saprophytic fungi grow on the fossil organic matter or on bacteria that utilize the organic matter. The fungi serve as food for the smallest invertebrates in the system which are then fed on by the larger invertebrates. The larger invertebrates including amphipods, isopods, decapods (shrimps), and snails are then fed upon by the blind catfishes in the San Antonio area. The toothless blindcat with its sucker mouth proba- 
bly feeds on organisms in the bottom sediments and may also use nutrients from organic material in those sediments. The widemouth blindcat is probably an opportunistic feeder eating anything it can get in its mouth including young toothless blindcats. In samples taken from San Antonio wells, the toothless blindcats were twice as abundant as the widemouth blindcats.

The Texas blind salamanders have been observed eating almost all of the available invertebrates in the San Marcos pool of the aquifer. At the present time salamanders are being kept for study at Southwest Texas State University Aquatic Station. Thirty-three preadults and adults are being held in a distribution chamber of the artesian well. They are fed with aquifer invertebrates and apparently eat all that are placed in their holding vessels. In the laboratory, seven juveniles are being held in aquaria at $20-22^{\circ} \mathrm{C}$. These young are observed feeding on all invertebrates they can get in their mouths, often including the juvenile stages of shrimps or the smaller species of amphipods.

In the San Marcos Pool of the aquifer, the dytiscid beetle, Haideoporus texanus, is found. This form is troglobitic, lacking eyes and pigmentation. This beetle may be another predator in this system since dytiscids often are predaceous. It is relatively rare in samples and also is very small $(4-5 \mathrm{~mm})$. Individuals kept in aquaria have been observed feeding on dead shrimp, $P a$ laemonetes antrorum.

The fauna of the Edwards Aquifer consists of at least 35 to 40 species of troglobites, many endemic. Most organisms studied to date have been larger than 500 micrometers. In terms of richness of troglobitic species, this aquifer is apparently either the most diverse or one of the most diverse subterranean aquatic ecosystems in the world.

\section{RÉSUMÉ}

Des études récentes sur l'Aquifère d'Edwards, système de cavités karstiques du Texas, montrent l'existence d'une communauté de troglobies aquatiques extrêmement diversifiée.

Les prélèvements au niveau des puits et des sources apportent une vision nouvelle de la dynamique de ce système fascinant, qui est sans doute l'écosystème souterrain le plus diversifié connu actuellement dans le monde.

\section{LITERATURE}

ARNOW, T. 1959. Ground-water geology of Bexar County, Texas. Texas Board of Water Engineers Bull. 5911.

EDWARDS UNDERGROUND WATER DISTRICT, 1977. Information bulletin. Edwards Underground Water District, San Antonio, Texas.

HOLSINGER, J.R., and G. LONGLEY. 1980. The subterranean amphipod crustacean fauna of an artesian well in Texas. Smithsonian Contributions to Zoology No. 308, Smithsonian Institution Press, Washington, D.C.

LONGLEY, G. 1978. Status of Typhlomolge (=Eurycea) rathbuni, the Texas blind salamander. End. Species Rep. 2. U.S. Fish and Wildlife Service, Albuquerque, N.M.

LONGLEY, G., and H. KARNEI 1978a. Status of Satan eurystomus Hubbs and Bailey, the widemouth blindcat. Contract No. 14-16-0002-77-035, U.S. Fish and Wildlife Service.

LONGLEY, G., and H. KARNEI 1978b. Status of Trogloglanis pattersoni Eigenmann, the toothless blindcat. Contract No. 14-16-0002-77-035, U.S. Fish and Wildlife Service.

PUENTE, T.C., 1976. Statistical analysis of water-level, spring flow, and stream flow data for 
the Edwards Aquifer in South Central Texas. Edwards Underground Water District, San Antonio, Texas.

SWEET, S.S. 1978. The development of diversity in Texas cave salamanders. Abstract, National Speleological Society Annual Meeting, New Braunfels, Texas.

U.S. DEPARTMENT OF THE INTERIOR, 1973. Memorandum: Performance of Edwards Aquifer when subjected to increasing well discharge. Bureau of Reclamation (Southwest Region). Looseleaf. 